\section{SOI: $1.1 / \mathrm{TAS} \quad$ DOI: $10.15863 / \mathrm{TAS}$ International Scientific Journal Theoretical \& Applied Science}

\author{
p-ISSN: 2308-4944 (print) e-ISSN: 2409-0085 (online) \\ Year: 2015 Issue: 10 Volume: 30
}

Published: $30.10 .2015 \quad \underline{\text { http://T-Science.org }}$
Elnur Latif oglu Hasanov Corresponding member of International Academy of Theoretical and Applied Sciences, Ph.D., Senior specialist of Ganja Department Azerbaijan National Academy of Sciences, Ganja, Azerbaijan 1-hasan@hotmail.com

SECTION 12. Geology. Anthropology.

Archaeology.

\title{
TO THE QUESTION ON RESEARCH OF HISTORIC-ETHNOGRAPHIC FEATURES OF GANJA IMAMZADE MAUSOLEUM
}

Abstract: Ganja is one of the most ancient cultural centers of Azerbaijan. This city has more than 4000 years old and here there is one of the main and ancient historical monuments of Muslim East civilization - Imamzada tomb. This important monument is situated 7 kilometres from the city of Ganja, on the right shore of Ganjachai river. Imamzada is recognized as one of the basic symbols of city.

Imamzada of Ganja was built in year 739, after the death of Ibrahim, son of the fifth Muslim imam Muhammed Bagir. At this monument were found some important historical sources - epitaphes. Imamzada tomb was completely built in the end of XIV century - the beginning of XV century.

But in XVII-XVIII centuries there were built a mosque, some temples and other constructions. During the centuries many visitors, guests from different parts of Azerbaijan, also from the other Muslim countries visit Ganja Imamzada monument.

Key words: Imamzade mausoleum, Ganja, Azerbaijan, historic-ethnographic research, historical past.

Language: English

Citation: Hasanov EL (2015) TO THE QUESTION ON RESEARCH OF HISTORIC-ETHNOGRAPHIC FEATURES OF GANJA IMAMZADE MAUSOLEUM. ISJ Theoretical \& Applied Science 10 (30): 32-34.

Soi: http://s-o-i.org/1.1/TAS-10-30-9 Doi: crossef http://dx.doi.org/10.15863/TAS.2015.10.30.9

\section{Introduction}

Imamzade Mausoleum, situated in one of the ancient scientific and cultural centers, Ganja State History-Culture Reserve, was built in 739, on site of the grave of the great-grandchild of Prophet Muhammad (s.a.a.), mevlana (majesty) Ibrahim, the grandson of Imam Ali ibn Husseyn and the son of the fifth imam Muhammad Al-Bagir and Umma Hakim Mugaya's daughter Sagaf.

Incidentally, the purpose of the mausoleum (and, in the future, the whole complex) is also explained by its name. Imamzada means "the descendant of imam," "from the family lineage of imam." At a result, society accepts Imamzade as a sacred place of worship.

As the result of the ahl al-bayt (designation in Islam for the holy family of the Prophet Muhammad (s.a.a.)) persecution in Umayyad Caliphate (661750), many of its members took refuge in the remote places of caliphate and mevlana Ibrahim emigrated to Ganja, one of the centers of the ancient Islamic culture.

Despite the fact that, Imam Muhammad AlBaqir (a) was buried in Madina in Baqi cemetery next to his father and grandfather, his son mevlana
Ibrahim was buried in Ganja, Azerbaijan located very far from the graves of his ancestors.

The mausoleum, built around the grave of mevlana Ibrahim in the VIII century, was enlarged in the XIV-XVI centuries, and subsidiary buildings around it were erected in the XVII-XVIII centuries.

The tomb is the most important part of the Imamzade mausoleum complex. The height of the dome of tomb building is $12 \mathrm{~m}$; the height of cupola is $2.7 \mathrm{~m}$ with diameter of $4.4 \mathrm{~m}$, covered with blue tiles.

Another designation for Imamzade, also known as the Göy (Blue) Imam Turbeh, according to different sources can be related to ancient belief of the Azerbaijanis to Göy Tanrl, from whom the Turkic dynasties claimed to be descended.

\section{Materials and methods}

The important historical inscriptions discovered in the internal wall of the tomb in the XX century by the well-known investigators - the deceased archaeologist, professor Isaac Jafarzade, as well as the outstanding scientist in the epigraphy, the active member of Azerbaijan National Academy of 
Sciences, academician Meshadikhanim Nematova were enciphered in the following way:

"He, Allah is eternal. This is the holy place, honorable paradise of the son of Imam Muhammad Baqir, may Allah's blessings be upon him, mevlana Ibrahim. After 120 years of his grandfather's death, he died. May he rest in peace."

This passage helped to understand, that the tomb was built on the grave of the imam's son in 738-739 A.D.

The area of Imamzade complex was included in the property of the Sheykhzamanovs - the descendants of Nizami Ganjavi, the great Azerbaijani poet and philosopher.

Through the centuries, people carried and protected this sacred site. Large-scaled restoration work was carried out inside of the Imamzade mausoleum following the orders of Javad Khan Ziyadoglu (1748-1804), the last khan of Ganja and one of the symbols of Azerbaijani patriotism and heroism. In 1878-79, per initiative of major-general Israfil bay Yadigarzada, fundamental repair work was carried out in the Imamzada complex.

At the beginning of the XX century, this place of pilgrimage was restored again by a group of Ganja intellectuals.

\section{Conclusion and Recommendations}

Azerbaijan is located on the border of Europe and Asia and has good natural geographical conditions - a mild climate, fertile lands, natural underground and over ground resources. This land is recognized to be one of the most ancient centers of civilizations. Two million years ago there were necessary conditions on these lands for the primitive man's living, creation, evolution and progress.

Ganja is one of the most ancient cultural centers of our country. This city has more than 4000 years old and here there is one of the main and ancient historical monuments of Muslim East civilization Imamzada tomb. This important monument is situated 7 kilometres from the city of Ganja, on the right shore of Ganjachai river. Imamzada is recognized as one of the basic symbols of city.

Imamzada of Ganja was built in year 739, after the death of Ibrahim, son of the fifth Muslim imam Muhammed Bagir. At this monument were found some important historical sources - epitaphes. Imamzada tomb was completely built in the end of XIV century - the beginning of XV century.
But in XVII-XVIII centuries there were built a mosque, some temples and other constructions. During the centuries many visitors, guests from different parts of Azerbaijan, also from the other Muslim countries visit Ganja Imamzada monument.

Members of well-known dynasties of Ganja such as the Sheykhzamanlis, the Pishnamaz-zadas, Mirza Mehdi Naji, including the descendants from the family lineage of Prophet Muhammad (s.a.a.) Mir Abbas Aga, as well as major-general Israfil bay Yadigarzada and other distinguished individuals were buried in this place of pilgrimage.

Ganja Imamzade complex also has been known for years as the shelter, that helped lonely people, people living in poor conditions, or facing sickness and homelessness.

Subsidiary buildings of Imamzade complex were used as an orphanage during former Soviet reign in 1930-1944s. This sacred place became a shelter for the little children from various ethnic backgrounds who suffered in the World War II. Nowadays, the members of different religions still come to pay their respect to this holy place.

The valuable experience of Azerbaijan in the sphere of interreligious dialogue and cooperation has been highly appreciated and is well-known to everyone in the world. These values were raised up to state policy level by national leader Heydar Aliyev.

President of the Republic of Azerbaijan Ilham Aliyev, who continuous strategy, laid down by Azerbaijani national leader, signed a number of decrees and orders for the protection and restoration of the religious and historical-architectural monuments. Project like these, that were carried out under the leadership of Mehriban Aliyeva, President of Heydar Aliyev Fundation, Goodwill ambassador of UNESCO and ISESCO, represent deep multicultural roots and traditions of coexistence of people of different religious and ethnic backgrounds.

According to seven decrees signed by Head of State Ilham Aliyev, "Imamzade" religious-historical complex was completely restored and now complements the architectural style of the city of Ganja.

At the present time, as one of the most valued places of pilgrimage of the Islamic world, the Imamzade museum complex in Ganja is a sacred place for local population, as well as pilgrims that come from different foreign countries.

\section{References:}

1. Agamalieva SM (1987) Goncharstvo Azerbaydzhana. Baku: Elm.
2. Cavadov QC (1977) Azərbaycanda ağacişləmə sənəti haqqında. AEM. III buraxılış. 


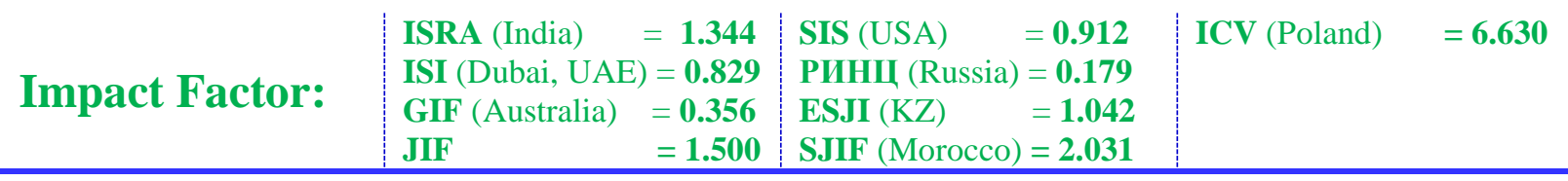

3. Ofəndiyev RS (1976) Azərbaycanın dekorativtətbiqi sənətləri. Bakı: İşıq.

4. Ohmədov FM (2007) Gəncənin tarix yaddaş1. Gəncə: Elm.

5. Gəncənin məhəllə adları (1978) Elm və həyat jurnalı, №10.

6. Guliyeva NM, Häsänov EL (2014) Die traditionelle Gändschänischen Teppiche von Zeitraum der Aserbaidschanischen Gelehrten und Dichter Mirsä Schäfi Waseh als ethnoanthropologische quelle (XIX Jahrhundert). European Applied Sciences, 2, pp. 3-5.

7. Hasanov EL (2015) Multidisciplinary approach to investigation of the basic handicraft branches of Ganja till the XX century. ISJ Theoretical \& Applied Science 1(21): 7-15. DOI: http://dx.doi.org/10.15863/TAS.2015.01.21.2

8. Hasanov EL (2015) To the Question on Research of Craftsmanship Traditions of Ganja of XIX - First Half of XX Centuries. Mediterranean Journal of Social Sciences, vol.
6, № 1, Part S1, pp. 433-437. Doi:10.5901/mjss.2015.v6n1s1p433

9. Həmidova İ (2000) Azərbaycan parça sənətinin tarixi inkişaf yolları. Elmi axtarışlar, VIII toplu, Bak1.

10. Həvilov HA (1991) Azərbaycan etnoqrafiyas1. Bakı: Elm

11. Məmmədov FN (1976) XIX əsrdə Gəncə şəhərinin ərazisi, əhalisi və idarəsi (1868-ci ilə qədər). Azərbaycan SSR Elmlər Akademiyasının Xəbərləri (Tarix, fəlsəfə və hüquq seriyas1), №3, pp. 30-37.

12. Mustafayev A (2001) Azərbaycanda sənətkarlıq. Bakı: Altay.

13. Smith WB, Hasanov EL (2013) Importance of handicraft traditions in investigation of history of urban culture in Ganja. ISJ Theoretical \& Applied Science 11(7): 61-66. doi: http://dx.doi.org/10.15863/TAS.2013.11.7.10

14. Tərlanov M, Ofəndiyev R (1960) Azərbaycan xalq sənəti. Bakı: Uşaq gənc nəşr. 